\title{
Peningkatan Hasil Belajar Sejarah melalui Pendekatan Kooperatif Teknik Jigsaw Siswa Kelas XII
}

\author{
Hariyono $^{(1)}$ \\ ${ }^{1}$ SMAN 1 Kesamben Kabupaten Blitar, \\ Email: ${ }^{1}$ hariyonosansa@gmail.com
}

\begin{abstract}
ABSTRAK
Berdasarkan data yang diperoleh sebelumnya diadakan tindakan sampai dengan tindakan siklus I, II, dan III , dapat disimpulkan bahwa Penerapan Pendekatan Kooperatif Teknik Jigsaw Dapat Meningkatkan hasil belajar Sejarah siswa kelas XII Di SMA Negeri 1 Kesamben Kab.Blitar ?. Sebagai gambaran untuk memperjelas keberhasilan PTK ini dapat kita lihat data dan grafik perbandingan antara kemampuan siswa sebelum tindakan dan sesudah tindakan .Dari hasil penelitian mulai dari kegiatan Pra Tindakan sampai dengan Kegiatan Tindakan Siklus I, II, dan III dapat disimpulkan sebagai berikut (1) Pembelajaran dengan menggunakan pendekatan kooperatif Teknik Jigsaw dapat meningkatkan Hasil Belajar Siswa siswa dalam: kerja kelompok dan kerja kelompok jigsaw (2) Dengan mengoptimalkan pengajaran dengan pendekatan koopoeratif Teknik Jigsaw, mampu meningkatkan hasil belajar Sejarah siswa kelas XII Di SMA Negeri 1 Kesamben Kab.Blitar. (3) Penggunaan teknik Jigsaw dalam pembelajaran Sejarah, ternyata dapat meningkatkan motivasi dan ketertarikan siswa terhadap materi Sejarah. Dari hasil pelaksanaan siklus III dapat disimpulkan melalui refleksi sebagai berikut: (1) Model pembelajaran dengan menggunakan pendekatan kooperatif teknik Jigsaw sangat penting dalam penciptaan keaktifan siswa dalam pembelajaran Sejarah . (2) Perpaduan ceramah diskusi, demonstrasi, dan pemecahan masalah cukup efektif dalam meningkatkan keaktifan siswa yang akhirnya berdampak positif dalam meningkatan hasil belajar siswa.
\end{abstract}

Kata kunci: hasil belajar, sejarah, kooperatif, jigsaw,

\section{PENDAHULUAN}

Bakat, minat, dan kecerdasan yang dimiliki oleh setiap siswa adalah obyek pelayanan pendidikan yang utama dan hal ini harus benar-benar dipahami oleh guru selaku pendidik. Oleh sebab itu proses pembekalan siswa dengan berbagai cabang ilmu pengetahuan harus dimulai sejak dini dan berlangsung dalam pembelajaran di kelas. Agar bakat, minat, dan kecerdasan yang dimiliki oleh setiap siswa bisa dimunculkan maka seorang guru harus mempunyai kompetensi dalam melatih dan mendidik. Kompetensi untuk memunculkan pembelajaran yang mampu mengembangkan segenap potensi yang dimiliki siswa baik koognitif, afektif maupun psikomotor atau yang mampu meningkatkan motivasi sekaligus hasil belajar siswa.

Pengorganisasian pembelajaran dikelas dengan metode dan strategi yang tepat adalah jawabannya. Sebab harus diakui bahwa proses pengajaran tidak akan berlangsung optimal apabila strategi yang digunakan tidak tepat (Berg, 1995:9). Dalam hal ini, sistem pengajaran sangat menentukan keberhasilan suatu proses belajar mengajar. Namun tidak selamanya metode dan strategi pembelajaran yang tepat dapat berlaku efektif di kelas.

Setelah peneliti mengadakan pengamatan untuk pembelajaran Sejarah di SMA Negeri 1 Kesamben Kab.Blitar, diketahui bahwa perencanaan pembelajaran telah disusun dengan baik dan disusun sebelum guru melaksanakan kegiatan pembelajaran. Metode yang digunakan guru sudah sesuai dengan materi bahan ajar, media pembelajaran sudah mewadahi, pengelolaan kelas sudah diatur bervariasi, namun hasil belajar siswa masih dibawah standar ketuntasan minimal. Kesimpulan peneliti tentang keadaan ini berdasarkan hasil pengamatan adalah bahwa hal ini disebabkan oleh pendekatan dan strategi belajar yang digunakan oleh guru belum menyentuh kebutuhan anak 
Keadaan ini dapat disebabkan oleh beberapa faktor: (1) Siswa dalam mengikuti pelajaran Sejarah pada umumnya mengalami banyak kesulitan dalam memahami materi pelajaran sejarah. (2) Siswa memiliki minat belajar yang kurang, hal ini ditunjukkan oleh rendahnya kemauan untuk bertanya saat siswa mengalami kesulitan dalam memahami materi. (3) Oleh karenanya pada saat kegiatan pembelajaran berlangsung, sikap siswa kurang bergairah, malas, cepat bosan, walaupun guru sudah berusaha menggunakan berbagai metode untuk membangkitkan minat belajar siswa, namun siswa masih kurang bersemangat untuk mempelajari Sejarah. (4) hanya ada beberapa siswa saja yang mau bertanya, sedangkan yang lainnya tidak tahu apa yang ditanyakan. Jika guru memberi pertanyaan hanya beberapa siswa saja yang mau menjawab, sedangkan lainnya takut untuk menjawab. (5) siswa yang aktif merupakan siswa yang berada dibarisan depan sedang siswa dibarisan belakang rata-rata pendiam (pasif) selama pembelajaran berlangsung

Jika keadaan seperti tersebut di atas dibiarkan, maka dampak yang terjadi adalah nilai Sejarah selalu di bawah standar, bahkan nilainya sangat rendah dibanding mata pelajaran yang lain. Untuk mengatasi permasalahan ini, peneliti melakukan kegiatan pembelajaran dengan pendekatan kooperatif teknik jigsaw. Dimana melalui kegiatan ini diharapkan interaksi antara guru dan siswa, antar siswa dengan siswa, muncul suasana yang baru dan menggairahkan, baik melalui diskusi kelompok, bertanya jawab maupun menyampaikan informasi kepada sesama teman dapat berjalan secara efektif dan efisien, sehingga pada akhirnya dapat meningkatkan hasil belajar siswa itu sendiri, baik aspek kognitif, afektif maupun psikomotor.

Berdasarkan identifikasi masalah diatas, maka rumusan masalah pada penelitian ini adalah: (1) Bagaimanakah pelaksanaan pembelajaran Sejarah melalui pendekatan kooperatif Teknik Jigsaw pada siswa kelas XII Di SMA Negeri 1 Kesamben Kab.Blitar? (2) Bagaimanakah peningkatan hasil belajar Sejarah melalui pendekatan kooperatif Teknik Jigsaw pada siswa kelas XII Di SMA Negeri 1 Kesamben Kab.Blitar? (2) Bagaimanakah respon siswa terhadap pendekatan kooperatif Teknik Jigsaw pada siswa kelas XII Di SMA Negeri 1 Kesamben Kab.Blitar?

Tujuan yang akan dicapai dalam penelitian ini sebagai berikut: (1) Untuk mengetahui pelaksanaan pembelajaran Sejarah melalui pendekatan kooperatif Teknik Jigsaw pada siswa kelas XII Di SMA Negeri 1 Kesamben Kab.Blitar? (2) Untuk mengetahui peningkatan hasil belajar Sejarah melalui pendekatan kooperatif teknik Jigsaw pada siswa kelas XII Di SMA Negeri 1 Kesamben Kab.Blitar? (3) Untuk mengetahui respon siswa terhadap pendekatan kooperatif Teknik Jigsaw pada siswa kelas XII Di SMA Negeri 1 Kesamben Kab.Blitar?

\section{METODE Rancangan Penelitian Tempat dan Subyek Penelitian}

Penelitian dilaksanakan di SMA Negeri 1 Kesamben Kab. Blitar. Jarak dari Kota Kecamatan Kurang lebih $1 \mathrm{Km}$, tepatnya di Desa Kesamben Kab. Blitar. Jumlah rombongan belajar sebanyak 18 kelas, dari kelas X sampai dengan kelas XII. Dilihat dari letak geografis, sebagian besar mata pencaharian orang tua wali murid adalah sebagai petani, sebagian PNS, pengusaha, pedagang, dan ABRI. Secara umum taraf peekonomian kelas menengah. Adapun Subyek Penelitian adalah Siswa Kelas XII Di SMAN 1 Kesamben Kab. Blitar .Pada Semester Ganjil Tahun Pelajaran 2015/2016 dengan jumlah siswa sebanyak 992 siswa .

\section{Jadwal Pelaksanaan Penelitian}

Pelaksanaan penelitian dimulai bulan September 2016 sampai dengan November 2015. Untuk penulisan dan pelaporan minggu pertama Oktober 2015. Persiapan dilaksanakan minggu II dan III September 2015, Tanggal 13, 15 September 2015, dan tanggal 20, 22 September 2015. Pelaksanaan penelitian, pengumpulan data dan pengolahan data pada minggu II, III, dan IV November 
Vol. 1 No. 1, Oktober 2017

2015, Siklus I (tanggal 8, 9, 10 November 2015); Siklus II (tanggal 15, 16, 17 November 2015); Siklus III (tanggal 22, 23, 24 November 2015). Penulisan dan pelaporan , pada minggu II, bulan Nopember 2013, (tanggal 8 Nopember 2015)

\section{Rancangan Pelaksanaan Penelitian}

Dalam rencana penelitian ini, Penulis merancang penelitian sebanyak 3 siklus dengan waktu dan materi yang berbeda, yaitu: (1) Siklus I, Sasaran penelitian adalah siswa kelas XII Di SMAN 1 Kesamben Kab. Blitar sebanyak 992 siswa. Materi Pembelajaran Perang dingin dan pengaruhnya bagi perkembangan dunia. Langkahlangkah kegiatan terdiri dari: Planning (perencanaan), Acting (pelaksanaan), Observing (pengamatan), dan Reflecting (refleksi). (2) Siklus II Sasaran penelitian adalah siswa kelas XII Di SMAN 1 Kesamben Kab. Blitar, sebanyak 992 siswa. Materi Pembelajaran Terbentuknya gerakan non blok dan pengaruhnya bagi perkembangan politik internasional. Langkah-langkah kegiatan terdiri dari: Planning (perencanaan), acting (pelaksanaan), Observing (pengamatan), dan reflecting (refleksi). Siklus III, Sasaran penelitian adalah siswa kelas XII Di SMAN 1 Kesamben Kab. Blitar, sebanyak 992 siswa. Materi Pembelajaran Perang teluk II masalah Irak menginvasi Kuwait. Langkah-langkah kegiatan terdiri dari: Planning (perencanaan), acting (pelaksanaan), Observing (pengamatan), dan reflecting (refleksi).

\section{Sumber Data dan Analisis Data Lembar Observasi Kegiatan Guru dan Siswa}

Lembar Observasi digunakan untuk mengamati aktivitas dan kreativitas guru dan siswa selama PTK, menggunakan teknik pengajaran langsung, juga untuk mengamati perubahan yang terjadi pada siswa setiap siklus. Adapun format Lembar Observasi yang akan digunakan adalah sebagai berikut:

Tabel 1. Lember Observasi Siswa

\begin{tabular}{|c|c|c|c|}
\hline No & $\begin{array}{c}\text { Jenis Kegiatan Guru/Siswa } \\
\text { Yang diamati }\end{array}$ & $\begin{array}{l}\text { Rentang } \\
\text { Skor }\end{array}$ & $\begin{array}{c}\text { Skor } \\
\text { Perolehan }\end{array}$ \\
\hline 1 & Peranan Guru sebagai fasilitator & $1-10$ & \\
\hline 2 & Belajar melalui pengalaman langsung & $1-10$ & \\
\hline 3 & Kebermaknaan pengalaman belajar & $1-10$ & \\
\hline 4 & Prakarsa siswa & $1-10$ & \\
\hline 5 & Keragaman kegiatan & $1-10$ & \\
\hline 6 & Keterlibatan mental siswa & $1-10$ & \\
\hline 7 & Keragaman media belajar & $1-10$ & \\
\hline 8 & Perhatian terhadap kebutuhan & $1-10$ & \\
\hline & Jumlah skor & 80 & \\
\hline
\end{tabular}

Untuk mengetahui tingkat keaktifan dalam pembelajaran, maka caranya adalah skor perolehan dibagi 80 dikalikan 100. Jika perolehan mencapai 65-100, termasuk Belajar Aktif tingkat tinggi, jika perolehan mencapai 45 - 64, termasuk Belajar Aktif tingkat sedang, dan jika perolehan mencapai $1-44$, termasuk Belajar Aktif tingkat rendah .

\section{Program Rencana Pembelajaran}

Pedoman pembelajaran di kelas yang disusun secara seksama oleh guru dengan mengacu pada kurikulum dan kisi-kisi materi (1) Perang dingin dan pengaruhnya bagi perkembangan dunis, (2)Terbentuknya gerakan non blok dan pengaruhnya bagi perkembangan pilitik Internasional, (3) Perang Teluk II tahun 1991 masalah Irak menginvasi Kwait dengan menggunakan teknik jiqsaw sebagai metode pembelajaran dikelas. 


\section{Lembar Soal Pre-test dan Post-tes}

Pre- tes diberikan kepada siswa dalam bentuk tertulis pada siklus I, siklus II, dan siklus III, dengan tujuan untuk mengetahui kemampuan dasar siswa sebelum memasuki pergantian materi pembelajaran.

Sedangkan post-tes diberikan kepada siswa dalam bentuk tulisan pada siklus I, II, dan III, dengan tujuan untuk mengetahui perkembangan kemampuan siswa dalam pembelajaran matematika, dengan menggunakan teknik pengajaran terarah sesuai dengan materi yang diajarkan. Analisis data dilakukan dengan menghitung rata-rata kelas dari prestasi belajar siswa dengan rumus:

\section{Rata-rata hasil belajar siswa $=\underline{\text { Skor X Jumlah Siswa nilai tertentu }}$ Jumlah siswa}

\section{Angket Respon Siswa}

Lembar kuisioner yang diberikan kepada siswa dalam rangka mengukur sejauhmana, respon siswa selaku obyek penelitian terhadap penggunaan teknik Jigsaw di dalam pembelajaran matematika di kelas. Adapun format lembar kuisiner adalah sebagai berikut:

Tabel 2. Angket Respon Siswa

\begin{tabular}{|c|c|c|c|c|c|}
\hline \multirow[b]{2}{*}{ No } & \multirow[b]{2}{*}{ Jenis Pertanyaan } & \multirow[b]{2}{*}{ Pra PTK } & \multicolumn{3}{|c|}{ Paska PTK ( \%) } \\
\hline & & & 1 & II & III \\
\hline 1 & $\begin{array}{l}\text { Siswa yang merasa senang } \\
\text { belajar Sejarah }\end{array}$ & & & & \\
\hline 2 & $\begin{array}{l}\text { Merasa senang memahami } \\
\text { konsep perang dingin dan } \\
\text { pengaruhny a bagi } \\
\text { perkembangan dunia }\end{array}$ & & & & \\
\hline 3 & $\begin{array}{l}\text { Siswa merasa senang belajar } \\
\text { dengan pendekatan Jigsaw }\end{array}$ & & & & \\
\hline 4 & $\begin{array}{l}\text { Siswa merasa termotivasi } \\
\text { belajarnya, memahami konsep } \\
\text { peranan Ir.Sukarno dalam } \\
\text { pembetukan gerakan non blok }\end{array}$ & & & & \\
\hline 5 & $\begin{array}{l}\text { Siswa merasa bisa membuat } \\
\text { model penemuan masalah- } \\
\text { masalah materi pembelajaran }\end{array}$ & & & & \\
\hline 6 & $\begin{array}{l}\text { Kesulitan yang dihadapi oleh } \\
\text { siswa }\end{array}$ & & & & \\
\hline$A$ & $\begin{array}{l}\text { Menguasai materi diskusi } \\
\text { kelompok belajar ( pok 6) }\end{array}$ & & & & \\
\hline$B$ & $\begin{array}{l}\text { Menjelaskana kepada anggota } \\
\text { kelompok (pok 4) }\end{array}$ & & & & \\
\hline$C$ & $\begin{array}{l}\text { Tanya jawab dalam belajar } \\
\text { kelompok }\end{array}$ & & & & \\
\hline$D$ & $\begin{array}{l}\text { Membuat contoh-contoh } \\
\text { kongkret (siswa boleh memilih } \\
\text { lebih dari satu) }\end{array}$ & & & & \\
\hline
\end{tabular}

Tahapan Pengajaran Setiap Siklus

Pada penelitian ini, peneliti menggunakan model siklus yang terdiri dari Siklus I, II, dan III. Pada Siklus I, guru melakukan tes awal (pre-tes) dengan materi " Perang dingin dan pengaruhnya bagi perkembangan dunia. Siklus II dengan materi : 
Vol. 1 No. 1, Oktober 2017

Terbentuknya gerakan non blok serta pengaruhnya bagi perkembangan politik internasional . siklus III materi Perang teluk II masalah Irak Menginvasi Kuwait. Selanjutnya guru melakukan tahapan permaian Jigsaw, yang meliputi (1) Guru mengajukan serangkaian pertanyaan kepada siswa, tujuannya untuk menjajaki pemikiran dan pengetahuan yang dimiliki oleh siswa. (2) Siswa secara berkelompok, diberi kesempatan yang cukup dalam membahas jawaban sesuai dengan materi. (3) Siswa diberi tugas membahas materi, mendalami materi, sampai dengan menguasai materi yang telah dibahas diberi waktu secukupnya. (4) Kemudian siswa membentuk kelompok Jigsaw (kelompok 4), dan masing-masing siswa disuruh mengajarkan materi yang sudah dikuasai pada kelompok 6, untuk disampaikan atau ditransfer kepada kelompok baru yaitu kelompok 4, (5) Setelah selesai siswa disuruh kembali ke tempat masing-masing, dan guru mencatat dan menyeleksi pendapat siswa. (6) Guru menyajikan poin-poin pembelajaran utama yang akan diajarkan, dan siswa menjelaskan kesesuaian jawaban mereka dengan poin-poin tersebut.

Tahapan pengajaran untuk siklus I, II, dan III dilakukan sama, namun dengan materi yang berbeda. Kegiatan ini dilakukan sambil mengadakan pengamatan untuk mengetahui tingkat keterlibatan siswa dalam proses pembelajaran matematika. Hal ini dilakukan guna menumbuhkan dan mendorong siswa untuk aktif dan kreatif dalam berfikir kritis melalui presentasi, mengkritik, menanggapi, bertanya, dan menjawab pertanyaan selama PTK, serta meningkatkan prestasi dan hasil belajarnya.

\section{HASIL \\ Siklus I \\ Kajian Awal Siklus I}

Peneliti memberikan pretest pra PTK untuk dijawab oleh siswa, untuk memperoleh gambaran umum tentang cara belajar siswa dan motivasinya terhadap pembelajaran matematika di kelas. Setelah itu guru peneliti melakukan tanya jawab dengan siswa tentang materi pembelajaran. Hal ini dilakukan untuk mengetahui tingkat kreativitas dan keaktifan siswa sesuai dengan teknik pembelajaran Sistem Permainan Jigsaw, yaitu: (1) Peranan guru sebagai fasilitator, (2) Belajar melalui pengalaman langsung, (3) Kebermaknaan pengalaman belajar, (4) Prakarsa siswa, (5) Keragaman kegiatan, (6) Keterlibatan mental siswa, (7) Keragaman Media belajar, dan (8) Perhatian terhadap kebutuhan

Disamping itu dari hasil pre-test yang dilakukan terhadap siswa guna mendapatkan data awal, terlihat hasil perolehan penguasaan materi pembelajaran seperti pada tabel berikut

Tabel 3. Data Hasil Pre-test Sebelum PTK Siklus I Kelas XII Di SMAN 1 Kesamben Kab.Blitar

\begin{tabular}{|l|l|l|l|}
\hline No. & Perolehan Skor & $\begin{array}{l}\text { Jumlah } \\
\text { Siswa }\end{array}$ & Skor X Jumlah Siswa \\
\hline 1 & 80 & 1 & 80 \\
\hline 2 & 75 & 2 & 150 \\
\hline 3 & 70 & 2 & 140 \\
\hline 4 & 65 & 2 & 130 \\
\hline 5 & 60 & 2 & 120 \\
\hline 6 & 55 & 2 & 110 \\
\hline 7 & 50 & 3 & 150 \\
\hline 8 & 45 & 3 & 135 \\
\hline 9 & 40 & 3 & 120 \\
\hline 10 & 35 & 3 & 105 \\
\hline 11 & 25 & 1 & 25 \\
\hline & Jumlah /Rata-rata & 24 & 52,71 \\
\hline
\end{tabular}


Vol. 1 No. 1, Oktober 2017

Dari data di atas, terlihat bahwa kemampuan siswa terhadap penguasaan materi sebelum diterapkan pembelajaran dengan sistem Jigsaw masih sangat rendah yaitu rata-rata 52,71.

\section{Pelaksanaan Tindakan Siklus I Perencanan}

Kegiatan yang dilakukan pada siklus I adalah (1) Membuat rencana pembelajaran atau skenario pembelajaran Jigsaw, sesuai materi yang diajarkan (2) Membuat instrument penelitian ; lembar observasi, quesioner , dan pre-test, (3) Membuat Silabus, (4) Membuat lembar kerja sesuai materi.

\section{Pelaksanaan}

Kegiatan dalam tahap ini adalah peneliti menyajikan materi pembelajaran sesuai rencana yang disusun yaitu Perang Dingin dan pengaruhnya bagi perkembangan dunia. Melalui teknik pembelajaran sistem Jigsaw. Kegiatan ini dilakukan dengan tahapan-tahapan pengajaran sebagai berikut (1) Guru memberikan input atau masukan tentang tujuan pembelajaran sesuai dengan materi waktu kurang lebih 5 menit, (2) Guru menjelaskan konsep tentang perang dingin dan pengaruhnya bagi perkembangan dunia. waktu yang dibutuhkan 10 menit Membagi siswa menjadi 4 kelompok (tiap kelompok 6 anak). (3) Memberi materi pelajaran kepada setiap kelompok untuk dibaca dan dipelajari, didiskusikan, dan dikuasai oleh setiap siswa waktu kurang lebih 20 menit. (4) Siswa mengerjakan tugas untuk didalami beserta kelompoknya. (5) Siswa dibentuk menjadi kelompok Jigsaw sesuai dengan aturan semula yaitu menjadi 6 kelompok, setiap kelompok 4 siswa. (6) Siswa dalam kelompok baru bertugas saling mengajari pengalaman yang baru didapat dari kelompok belajar sebelumnya. (7) Setelah selesai siswa disuruh kembali ke tempat masing-masing, untuk menjawab pertanyaan yang masih tersisa secara akurat. (8) Guru mencatat siswa yang aktif dan pasif dalam daftar observasi. (9) Pada pertemuan berikutnya yaitu pertemuan 2 siklus I dilakukan kegiatan yang sama sepertti pada pertemuan 1 . (10) Kemudian pada akhir pertemuan 2 siswa mengerjakan test tulis, dan menjawab questioner.

\section{Pengamatan}

Pada saat pengamatan dilakukan peneliti dan pengamat mencatat kejadiankejadian melalui Pendekatan Kooperatif Teknik Jigsaw. Adapun hasil pengamatan terhadap siswa tertera pada tabel berikut ini

\section{Tabel 4}

Data Tingkat Keaktifan Siswa Sesudah Tindakan Siklus I Teknik Jigsaw

\begin{tabular}{|l|l|l|l|}
\hline No & $\begin{array}{l}\text { Jenis Kegiatan Guru/Siswa } \\
\text { Yang diamati }\end{array}$ & $\begin{array}{l}\text { Rentang } \\
\text { Skor }\end{array}$ & $\begin{array}{l}\text { Skor } \\
\text { Perolehan }\end{array}$ \\
\hline 1 & Peranan Guru sebagai fasilitator & $1-10$ & 4 \\
\hline 2 & Belajar melalui pengalaman langsung & $1-10$ & 3 \\
\hline 3 & Kebermaknaan pengalaman belajar & $1-10$ & 3 \\
\hline 4 & Prakarsa siswa & $1-10$ & 2 \\
\hline 5 & Keragaman kegiatan & $1-10$ & 6 \\
\hline 6 & Keterlibatan mental siswa & $1-10$ & 5 \\
\hline 7 & Keragaman media belajar & $1-10$ & 6 \\
\hline 8 & Perhatian terhadap kebutuhan & $1-10$ & 5 \\
\hline & Jumlah skor & 80 & 34 \\
\hline
\end{tabular}

Jumlah skor yang diperoleh dari hasil pengamatan tercapai 34, jika diprosentase, maka tingkat keaktifan siswa pada siklus I tercapai $42,5 \%$ yang berarti kualitas keaktifan siswa pada siklus I ini tergolong masih rendah. 
Selanjutnya hasil posttest pada siklus I sudah menunjukkan adanya kemajuan dibandingkan sebelumnya. Hal ini dapat dilihat pada tabel berikut:

Tabel 5

\section{Data Hasil Post test Pada Siklus I Kelas XII SMAN 1 Kesamben Kab.Blitar}

\begin{tabular}{|l|l|l|l|}
\hline No. & Perolehan Skor & Jumlah Siswa & Skor X Jumlah Siswa \\
\hline 1 & 70 & 1 & 90 \\
\hline 2 & 65 & 2 & 170 \\
\hline 3 & 60 & 2 & 160 \\
\hline 4 & 55 & 2 & 150 \\
\hline 5 & 90 & 2 & 140 \\
\hline 6 & 85 & 2 & 130 \\
\hline 7 & 80 & 2 & 120 \\
\hline 8 & 75 & 2 & 110 \\
\hline 9 & 50 & 3 & 150 \\
\hline 10 & 45 & 2 & 135 \\
\hline 11 & 40 & 2 & 40 \\
\hline 12 & 35 & 2 & 70 \\
\hline & Jumlah & 24 & 61,04 \\
& /Rata-rata & & \\
\hline
\end{tabular}

Dari data di atas, terlihat bahwa kemampuan siswa terhadap penguasaan materi setelah diterapkan pembelajaran dengan Teknik Jigsaw rata-ratanya sudah ada peningkatan, namun belum signifikan.

\section{Refleksi}

Berdasarkan hasil refleksi lembar observasi oleh pengamat, dan lembar penilaian kemampuan penguasaan materi pembelajaran tentang Perang dingin dan pengaruhnya bagi perkembangan dunia setelah siklus I ini berakhir, maka dapat disimpulkan sebagai berikut (1) Contoh-contoh yang ditunjukkan siswa sudah mengalami kemajuan dan benar perlu ditingkatkan, (2) Kerjasama kelompok dalam memecahkan masalah atau menjawab suatu latihan soal sudah cukup baik dan perlu ditingkatkan pada siklus berikutnya, (3) Dalam penerapan teknik Jigsaw, hendaknya guru menjelaskan target yang diharapkan dalam pembelajaran.

\section{Siklus II}

Pada Siklus II, proses pembelajaran sama dengan siklus I, dimulai dengan pretest dan hasilnya dapat diketahui sebagai berikut

\section{Tabel 6}

Data Hasil Pretest Sebelum PTK Siklus II Kelas XII Di SMAN 1 Kesamben -Blitar

\begin{tabular}{|l|l|l|l|}
\hline No. & Perolehan Skor & Jumlah Siswa & Skor X Jumlah Siswa \\
\hline 1 & 80 & 2 & 160 \\
\hline 2 & 75 & 2 & 150 \\
\hline 3 & 60 & 2 & 140 \\
\hline 4 & 55 & 2 & 130 \\
\hline 5 & 70 & 2 & 120 \\
\hline 6 & 65 & 3 & 165 \\
\hline 7 & 50 & 3 & 150 \\
\hline 8 & 45 & 3 & 135 \\
\hline 9 & 40 & 2 & 80 \\
\hline 10 & 35 & 2 & 70 \\
\hline 11 & 25 & 1 & 25 \\
\hline
\end{tabular}




\begin{tabular}{l|l|l} 
Jumlah & 24 & 55,21 \\
/Rata-rata & 24 &
\end{tabular}

Dari data di atas, terlihat bahwa kemampuan siswa terhadap penguasaan materi sebelum diterapkan pembelajaran dengan Pendekatan Kooperatif Teknik Jigsaw pada siklus II rata-ratanya masih rendah yaitu 55,21.

\section{Perencanan}

Kegiatan yang dilakukan pada siklus II sama seperti pada siklus I, yaitu (1) Membuat rencana pembelajaran dengan materi Terbentuknya negara non blok serta pengaruhnya bagi perkembangan politik Internasional, (2) Memberi penjelasan dan contoh latihan, menyampaikan hasil diskusi kelompok 6 kepada anggota kelompok 4. (3) Dijelaskan kembali tentang apa yang harus dikerjakan siswa sesuai kelompok Jigsaw. (4) Dilakukan latihan tentang pengisian test, serta penjelasan lain sesuai kondisi yang diharapkan.

\section{Pelaksanaan}

Kegiatan dalam tahap ini adalah peneliti menyajikan materi pembelajaran sesuai rencana yang disusun yaitu Terbentuknya Negara non blok serta pengaruhnya bagi perkambangan politik Internasional" melalui teknik Jigsaw Kegiatan ini dilakukan dengan tahapan-tahapan pengajaran sebagai berikut (1) Guru memberikan input atau masukan tentang tujuan pembelajaran sesuai dengan materi waktu kurang lebih 5 menit. (2) Guru menjelaskan konsep tentang Terbentuknya gerakan non blok waktu yang dibutuhkan 10 menit. (3) Membagi siswa menjadi 4 kelompok. (4) Memberi materi pelajaran kepada setiap kelompok untuk dibaca dan dipelajari, didiskusikan, dan dikuasai oleh setiap siswa waktu kurang lebih 20 menit. (5) Siswa mengerjakan tugas untuk didalami beserta kelompoknya. (6) Siswa dibentuk menjadi kelompok Jigsaw sesuai dengan aturan semula yaitu menjadi 6 kelompok, setiap kelompok 4 siswa. (7) Siswa dalam kelompok baru bertugas saling mengajari pengalaman yang baru (8) didapat dari kelompok belajar sebelumnya. (9) Setelah selesai siswa disuruh kembali ke tempat masing-masing, untuk menjawab pertanyaan yang masih tersisa secara akurat (10) Guru mencatat siswa yang aktif dan pasif dalam daftar observasi. (11) Pada pertemuan berikutnya yaitu pertemuan 2 siklus II dilakukan kegiatan yang sama seperti pada pertemuan 1. (12) Kemudian pada akhir pertemuan 2, Siklus II siswa mengerjakan test tulis, dan menjawab kuesioner .

\section{Pengamatan}

Pada saat tahapan ini dilakukan, peneliti dan pengamat melakukan pengamatan kegiatan pengajaran dengan materi " terbentuknya geraakan non blok serta pengaruhnya bagi perkembangan politik Internasional " melalui Pendekatan Kooperatif Teknik Jigsaw berikut ini :

Adapun hasil pengamatan terhadap kadar keaktifan siswa tertera pada tabel

Tabel 7

Data Tingkat Keaktifan Siswa Sesudah Tindakan Siklus II Teknik Jigsaw Kelas XII Di SMAN 1 Kesamben -Blitar

\begin{tabular}{|l|l|l|l|}
\hline No & $\begin{array}{l}\text { Jenis Kegiatan Guru/Siswa } \\
\text { Yang diamati }\end{array}$ & $\begin{array}{l}\text { Rentang } \\
\text { Skor }\end{array}$ & $\begin{array}{l}\text { Skor } \\
\text { Perolehan }\end{array}$ \\
\hline 1 & Peranan Guru sebagai fasilitator & $1-10$ & 4 \\
\hline 2 & Belajar melalui pengalaman langsung & $1-10$ & 5 \\
\hline 3 & Kebermaknaan pengalaman belajar & $1-10$ & 5 \\
\hline 4 & Prakarsa siswa & $1-10$ & 4 \\
\hline 5 & Keragaman kegiatan & $1-10$ & 7 \\
\hline 6 & Keterlibatan mental siswa & $1-10$ & 6 \\
\hline
\end{tabular}




\begin{tabular}{|l|l|l|l|}
\hline No & $\begin{array}{l}\text { Jenis Kegiatan Guru/Siswa } \\
\text { Yang diamati }\end{array}$ & $\begin{array}{l}\text { Rentang } \\
\text { Skor }\end{array}$ & $\begin{array}{l}\text { Skor } \\
\text { Perolehan }\end{array}$ \\
\hline 7 & Keragaman media belajar & $1-10$ & 7 \\
\hline 8 & Perhatian terhadap kebutuhan & $1-10$ & 7 \\
\hline & Jumlah skor & 80 & 47 \\
\hline
\end{tabular}

Dari hasil pengamatan pada Siklus II kegiatan diskusi kelas skor yang dicapai sebesar 47, jika diprosentase, maka tingkat keaktifan siswa mencapai 58,75\% yang berarti kualitas keaktifan siswa pada siklus II ini tergolong sedang. Walaupun tergolong sedang kualitas keaktifan siswa pada siklus II sudah ada peningkatan dari siklus I, yaitu meningkat dari $42,50 \%$ menjadi $58,75 \%$ (meningkat $16,25 \%$ )

Selanjutnya hasil posttest pada siklus II sudah menunjukkan adanya kemajuan dibandingkan sebelumnya. Hal ini dapat dilihat pada table berikut:

Tabel 8

Data Hasil Posttest Pada Siklus II Kelas XII Di SMAN 1 Kesamben Kab.Blitar

\begin{tabular}{|l|l|l|l|}
\hline No. & Perolehan Skor & Jumlah Siswa & Skor X Jumlah Siswa \\
\hline 1 & 90 & 2 & 180 \\
\hline 2 & 85 & 3 & 255 \\
\hline 3 & 80 & 3 & 240 \\
\hline 4 & 75 & 3 & 225 \\
\hline 5 & 70 & 2 & 140 \\
\hline 6 & 65 & 2 & 130 \\
\hline 7 & 60 & 2 & 120 \\
\hline 8 & 55 & 1 & 55 \\
\hline 9 & 50 & 2 & 100 \\
\hline 10 & 45 & 1 & 45 \\
\hline 11 & 40 & 1 & 40 \\
\hline 12 & 35 & 1 & 35 \\
\hline 13 & 30 & 1 & 30 \\
\hline & Jumlah & 24 & 66,45 \\
& Rata-rata & & \\
\hline
\end{tabular}

Dari data di atas, terlihat bahwa kemampuan siswa terhadap penguasaan materi setelah diterapkan pembelajaran dengan teknik Jigsaw rata-ratanya sudah ada peningkatan dibandingkan dengan siklus I yaitu dari 61,04 menjadi 66,46 ada peningkatan sebesar $5,42 \%$, namun demikian perlu ditingkatkan lagi pada siklus III.

\section{Refleksi}

Berdasarkan hasil refleksi lembar observasi oleh pengamat, dan lembar penilaian kemampuan penguasaan materi pembelajaran tentang: "Terbentunya gerakan non blok serta pengaruhnya bagi perkembangan politik Internasional " setelah siklus II ini berakhir, maka dapat disimpulkan sebagai berikut (1) Contoh-contoh yang ditunjukkan siswa sudah bagus dan benar perlu dipertahankan (2) Kerjasama kelompok dalam memecahkan masalah atau menjawab suatu latihan soal sudah baik dan perlu dipertahankan (3) Dari langkah tersebeut siswa mempunyai gambaran yang jelas tentang permasalahan yang ada pada materi Terbentunya gerakan non blok serta pengaruhnya bagi perkembangan politik Internasional. (4) Masih perlu penjelasan bagaimana cara menyampaikan materi kepada temannya mengajukan dan menjawab pertanyaan. (5) Diperlukan pembelajaran tersendiri tentang bagaimana cara menyampaikan materi kepada temannya dalam kelompok jigsaw yang runtut sesuai alur berfikir yang benar 


\section{Siklus III}

Sebagaimana yang telah dilakukan pada siklus sebelumnya, kegiatan pembelajaran pada siklus III, terlebih dahulu dilakukan pretest .

Adapun hasil pre-test pada siklus III prosentasenya adalah sebagai berikut :

\section{Tabel 9}

\section{Data Hasil Pretest Sebelum PTK Siklus III Kelas XII Di SMAN 1 Kesamben -Blitar}

\begin{tabular}{|l|l|l|l|}
\hline No. & Perolehan Skor & Jumlah Siswa & Skor X Jumlah Siswa \\
\hline 1 & 80 & 3 & 240 \\
\hline 2 & 75 & 3 & 225 \\
\hline 3 & 70 & 3 & 210 \\
\hline 4 & 65 & 2 & 130 \\
\hline 5 & 60 & 2 & 120 \\
\hline 6 & 55 & 3 & 165 \\
\hline 7 & 50 & 3 & 150 \\
\hline 8 & 45 & 1 & 45 \\
\hline 9 & 40 & 2 & 80 \\
\hline 10 & 35 & 1 & 35 \\
\hline 11 & 25 & 1 & 25 \\
\hline & Jumlah & 24 & 59,38 \\
& /Rata-rata & & \\
\hline
\end{tabular}

Dari data di atas, terlihat bahwa kemampuan siswa terhadap penguasaan materi sebelum diterapkan pembelajaran dengan sistem Jigsaw pada siklus II rataratanya masih rendah yaitu 59,38 .

\section{Perencanan}

Kegiatan yang dilakukan pada siklus III sama seperti pada siklus II, yaitu (1) Membuat rencana pembelajaran dengan materi Perang Teluk II Masalah Irak Menginvasi Kwait. (2) Membuat lembar kerja siswa disesuaikan dengan langkah pembelajaran. (3) Membuat daftar pertanyaan. (4) Memberi penjelasan dan contoh latihan, menyampaikan hasil diskusi kelompok 6 kepada anggota kelompok 4. (5) Dijelaskan kembali tentang apa yang harus dikerjakan siswa sesuai kelompok Jigsaw (6) Dilakukan latihan tentang pengisian test, serta penjelasan lain sesuai kondisi yang diharapkan.

\section{Pelaksanaan}

Kegiatan dalam tahap ini adalah peneliti menyajikan materi pembelajaran sesuai rencana yang disusun pada siklus III yaitu : "Terbentunya gerakan non blok serta pengaruhnya bagi perkembangan politik Internasional melalui pendekatan kooperatif teknik Jigsaw. Kegiatan ini dilakukan dengan tahapan-tahapan pengajaran sebagai berikut (1) Guru memberikan input atau masukan tentang tujuan pembelajaran sesuai dengan materi waktu kurang lebih 5 menit (2) Guru menjelaskan konsep tentang:" Terbentunya gerakan non blok serta pengaruhnya bagi perkembangan politik Internasional' waktu yang dibutuhkan 10 menit. (3) Guru menguatkan kembali pada 4 kelompok (tiap kelompok 6 anak) dan membagi tugas kepada kelompok masing-masing. (4) Memberi materi pelajaran kepada setiap kelompok untuk dibaca dan dipelajari, didiskusikan, dan dikuasai oleh setiap siswa waktu kurang lebih 20 menit. (5) Siswa mengerjakan tugas untuk didalami beserta kelompoknya. (6) Siswa mengelompok sesuai kelompok Jigsaw sesuai dengan aturan semula yaitu menjadi 6 kelompok, setiap kelompok 4 siswa. (7) Siswa dalam kelompok Jigsaw mempunyai tugas yang sama seperti pada siklus II yaitu saling mengajari pengalaman yang baru didapat dari kelompok belajar 6 anak. (8) Setelah selesai siswa disuruh kembali ke tempat masing-masing, untuk menjawab pertanyaan 
yang masih tersisa secara akurat. (9) Guru mencatat siswa yang aktif dan pasif dalam daftar observasi, (10) Pada pertemuan berikutnya yaitu pertemuan 2 siklus III dilakukan kegiatan yang sama seperti pada pertemuan 1. (11) Kemudian pada akhir pertemuan 2, Siklus III siswa mengerjakan test tulis, dan menjawab quesioner.

\section{Pengamatan}

Pada saat tahapan ini dilakukan, peneliti dan pengamat melakukan pengamatan kegiatan pengajaran dengan materi Terbentunya gerakan non blok serta pengaruhnya bagi perkembangan politik Internasional melalui sistem pengajaran Jigsaw.

Adapun hasil pengamatan terhadap kadar keaktifan siswa tertera pada tabel berikut ini :

Tabel 10

Data Tingkat Keaktifan Siswa Sesudah Tindakan Siklus III Teknik Jigsaw Kelas XII Di SMAN 1 Kesamben Kab.Blitar

\begin{tabular}{|l|l|l|l|}
\hline No & $\begin{array}{l}\text { Jenis Kegiatan Guru/Siswa } \\
\text { Yang diamati }\end{array}$ & $\begin{array}{l}\text { Rentang } \\
\text { Skor }\end{array}$ & $\begin{array}{l}\text { Skor } \\
\text { Perolehan }\end{array}$ \\
\hline 1 & Peranan Guru sebagai fasilitator & $1-10$ & 8 \\
\hline 2 & Belajar melalui pengalaman langsung & $1-10$ & 7 \\
\hline 3 & Kebermaknaan pengalaman belajar & $1-10$ & 7 \\
\hline 4 & Prakarsa siswa & $1-10$ & 8 \\
\hline 5 & Keragaman kegiatan & $1-10$ & 9 \\
\hline 6 & Keterlibatan mental siswa & $1-10$ & 8 \\
\hline 7 & Keragaman media belajar & $1-10$ & 8 \\
\hline 8 & Perhatian terhadap kebutuhan & $1-10$ & 9 \\
\hline & Jumlah skor & 80 & 64 \\
\hline
\end{tabular}

Pada tabel di atas Jumlah skor yang diperoleh dari hasil pengamatan mencapai 64 atau $80 \%$, yang berarti kualitas keaktifan siswa pada siklus III ini tergolong tinggi, dan sudah sangat signifikan.. Kalau kita bandingkan keaktifan siswa dengan siklus II hasilnya sudah sangat signifikan yaitu dari 58,75 \% menjadi $80 \%$ ada peningkatan $21,25 \%$, dan jika dibandingkan dengan siklus I, ada peningkatan yang sangat tajam yaitu dari 42,50 \% menjadi $80 \%$ (meningkat 37,50\%) Hal ini berarti setelah diterapkan pengajaran Teknik Jigsaw, kadar keaktifan siswa mulai dari siklus I, ke siklus II sampai siklus III mengalami kenaikan yang signifikan dan berdampak pada peningkatan hasil belajar siswa sesuai dengan target yang diharapkan.

Selanjutnya hasil posttest pada siklus III sudah menunjukkan adanya peningkatan yang signifikan. Hal ini dapat dilihat pada tabel berikut :

Tabel 11

Data Hasil Posttest Pada Siklus III Kelas XII Di SMAN 1 Kesamben Kab.Blitar

\begin{tabular}{|l|l|l|l|}
\hline No. & Perolehan Skor & Jumlah Siswa & Skor X Jumlah Siswa \\
\hline 1 & 95 & 2 & 190 \\
\hline 2 & 90 & 3 & 270 \\
\hline 3 & 85 & 3 & 255 \\
\hline 4 & 80 & 3 & 240 \\
\hline 5 & 75 & 4 & 300 \\
\hline 6 & 70 & 4 & 280 \\
\hline 7 & 65 & 2 & 130 \\
\hline 8 & 60 & 1 & 60 \\
\hline
\end{tabular}




\begin{tabular}{|l|l|l|l|}
\hline 9 & 55 & 2 & 110 \\
\hline & $\begin{array}{l}\text { Jumlah } \\
\text { Rata-rata }\end{array}$ & 24 & 76,46 \\
\hline
\end{tabular}

Dari data di atas, terlihat bahwa kemampuan siswa terhadap penguasaan materi setelah diterapkan pembelajaran dengan Teknik Jigsaw mengalami peningkatan yang sangat signifikan dibandingkan dengan siklus II yaitu dari 66,46 menjadi 76,46 ada peningkatan sebesar $10 \%$, dan jika dibandingkan dengana siklus I kenaikannya sangat tajam yaitu dari $61,04 \%$ menjadi $76,46 \%$ ada kenaikan sebesar $15,42 \%$. Dengan peningkatan yang cukup tajam dari sebelum tindakan dan sesudah tindakan dengan menggunakan teknik Jigsaw hal ini dapat disimpulkan bahwa pembelajaran dengan teknik Jigsaw sangat efektif dalam meningkatkan keaktifan siswa dan hasil belajar siswa pada mata pelajaran matematika siswa kelas XII Di SMAN 1 Kesamben -Blitar.

\section{Refleksi}

Dari hasil pelaksanaan siklus III dapat disimpulkan melalui refleksi sebagai berikut (1) Model pembelajaran dengan menggunakan pendekatan kooperatif teknik Jigsaw sangat penting dalam penciptaan keaktifan siswa dalam pembelajaran Sejarah. (2) Perpaduan ceramah diskusi, demonstrasi, dan pemecahan masalah cukup efektif dalam meningkatkan keaktifan siswa yang akhirnya berdampak positif dalam meningkatan hasil belajar siswa.

\section{PEMBAHASAN}

Berdasarkan data yang diperoleh sebelumnya diadakan tindakan sampai dengan tindakan siklus I, II, dan III , dapat disimpulkan bahawa Penerapan Pendekatan Kooperatif Teknik Jigsaw Dapat Meningkatkan hasil belajar Sejarah siswa kelas XII Di SMAN 1 Kesamben Kab.Blitar?

Sebagai gambaran untuk memperjelas keberhasilan PTK ini dapat kita lihat data dan grafik perbandingan antara kemampuan siswa sebelum tindakan dan sesudah tindakan, seperti tabel berikut ini

Tabel 11

Perbandingan Tingkat Kemampuan Dan Keaktifan Siswa

Dalam Penerapan Pendekatan Kooperatif Teknik Jigsaw Pada Mata Pelajaran Sejarah Kelas XII Di SMAN 1 Kesamben Kab.Blitar Selama Siklus I s.d. Siklus III

\begin{tabular}{|c|c|c|c|c|}
\hline No & Jenis Kemampuan & $\begin{array}{c}\text { Rata-rata } \\
\text { Siklus I }\end{array}$ & $\begin{array}{c}\text { Rata-rata } \\
\text { Siklus II }\end{array}$ & $\begin{array}{c}\text { Rata-rata } \\
\text { Siklus III }\end{array}$ \\
\hline 1 & Pre-test & 52,71 & 55,21 & 59,38 \\
\hline 2 & Keaktifan Siswa & 42,50 & 58,75 & 80,00 \\
\hline 3 & Pos-test & 61,04 & 66,46 & 76,46 \\
\hline
\end{tabular}

Dari Data tersebut dapat digambarkan dalam diagram batang sebagaimana di bawah ini : 


\section{Grafik 1}

\section{Grafik Perbandingan Kemampuan dan Keaktifan Siswa} Dalam Penerapan Teknik Jigsaw Pada Siklus I, II, III

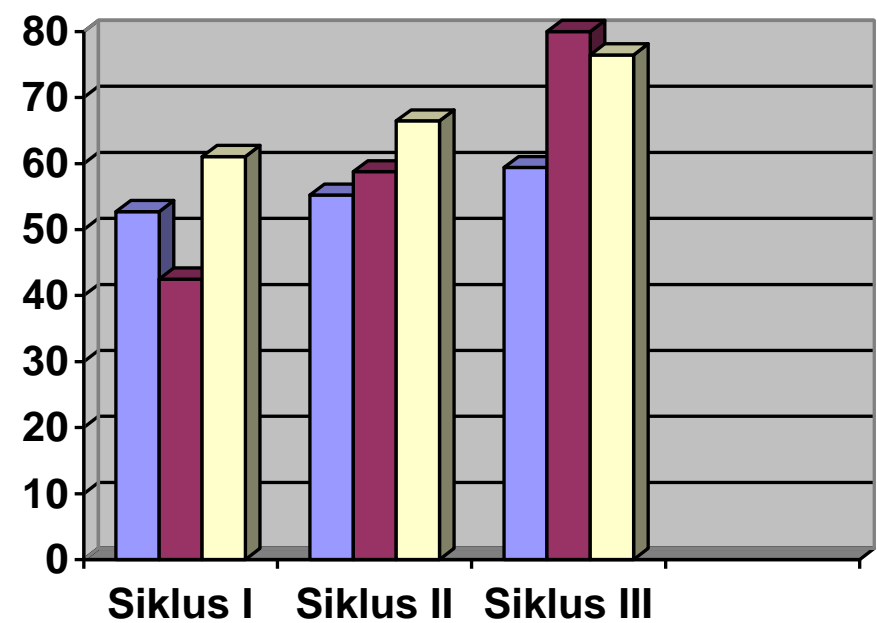

\begin{tabular}{|l|}
\hline Pre Test \\
$\square$ Keaktifan \\
$\square$ Posttest
\end{tabular}

Selain dari tes yang dilakukan, peneliti juga mencatat beberapa kemajuan dari hasil Kuesioner yaitu

Tabel 13. Hasil Kuesioner

\begin{tabular}{|c|c|c|c|c|c|}
\hline \multirow[b]{2}{*}{ No } & \multirow[b]{2}{*}{ Jenis Pertanyaan } & \multirow[b]{2}{*}{ Pra PTK } & \multicolumn{3}{|c|}{ Paska PTK ( \%) } \\
\hline & & & 1 & II & III \\
\hline 1 & $\begin{array}{l}\text { Siswa yang merasa senang } \\
\text { belajar Sejarah }\end{array}$ & 31,25 & 55,65 & 75,45 & 90,75 \\
\hline 2 & $\begin{array}{l}\text { Merasa senang memahami } \\
\text { konsep Perang dingin dan } \\
\text { pengaruhnya bagi } \\
\text { perkembangan dunia }\end{array}$ & 37,75 & 62,25 & 70,50 & 87,25 \\
\hline 3 & $\begin{array}{l}\text { Siswa merasa senang belajar } \\
\text { dengan pendekatan Jigsaw }\end{array}$ & 67,00 & 69,75 & 75,50 & 92,50 \\
\hline 4 & $\begin{array}{l}\text { Siswa merasa termotivasi } \\
\text { belajarnya, memahami konsep } \\
\text { dan Ide Ir.Sukarno dalam } \\
\text { membentuk gerakan non blok }\end{array}$ & 35,21 & 50,00 & 68,45 & 84,50 \\
\hline 5 & $\begin{array}{l}\text { Siswa merasa bisa membuat } \\
\text { model penemuan masalah- } \\
\text { masalah materi pembelajaran }\end{array}$ & 25,55 & 52,45 & 70,06 & 85,25 \\
\hline 6 & $\begin{array}{l}\text { Kesulitan yang dihadapi oleh } \\
\text { siswa }\end{array}$ & - & - & - & - \\
\hline a & $\begin{array}{l}\text { Menguasai materi diskusi } \\
\text { kelompok belaiar ( pok 6) }\end{array}$ & $\begin{array}{c}5 \\
\text { siswa }\end{array}$ & $\begin{array}{c}3 \\
\text { siswa }\end{array}$ & $\begin{array}{c}2 \\
\text { siswa }\end{array}$ & $\begin{array}{c}2 \\
\text { siswa }\end{array}$ \\
\hline$b$ & $\begin{array}{l}\text { Menjelaskana kepada anggota } \\
\text { kelompok (pok 4) }\end{array}$ & 12 siswa & 10 siswa & 8 siswa & $\begin{array}{c}5 \\
\text { siswa }\end{array}$ \\
\hline$c$ & $\begin{array}{l}\text { Tanya jawab dalam belajar } \\
\text { kelompok }\end{array}$ & $\begin{array}{c}8 \\
\text { siswa }\end{array}$ & $\begin{array}{c}7 \\
\text { siswa }\end{array}$ & $\begin{array}{c}5 \\
\text { siswa }\end{array}$ & 2 siswa \\
\hline$D$ & Membuat contoh-contoh & 15 siswa & 11 siswa & 8 siswa & 4 siswa \\
\hline
\end{tabular}


Melalui data diatas dapat diketahui bahwa secara bertahap dari siklus I hingga siklus III penggunaan teknik Jigsaw dalam pembelajaran Sejarah ternyata dapat meningkatkan motivasi dan ketertarikan siswa terhadap materi Sejarah.

\section{KESIMPULAN}

Dari hasil penelitian mulai dari kegiatan Pra Tindakan sampai dengan Kegiatan Tindakan Siklus I, II, dan III dapat disimpulkan sebagai berikut (1) Pembelajaran dengan menggunakan pendekatan kooperatif Teknik Jigsaw dapat meningkatkan Hasil Belajar Siswa siswa dalam kerja kelompok jigsaw. (2) Dengan mengoptimalkan pengajaran dengan pendekatan koopoeratif Teknik Jigsaw, mampu meningkatkan hasil belajar Sejarah siswa kelas XII Di SMAN 1 Kesamben Kab.Blitar. (3) Penggunaan teknik Jigsaw dalam pembelajaran matematika, ternyata dapat meningkatkan motivasi dan ketertarikan siswa terhadap materi Sejarah

\section{SARAN}

Bagi Siswa, Untuk meningkatkan kreativitas dalam kegiatan pembelajaran sehingga menemukan cara-cara dalam mengikuti pembelajaran yang bermakna. Bagi Guru, Untuk menambah wawasan kegiatan pembelajaran yang bermakna, dengan menggunakan berbagai macam cara teknik pembelajaran sehingga dapat ditemukan sistem pengajaran yang bermutu. Bagi Pihak Sekolah, Sebagai bahan masukan dan pertimbangan guna memberikan pembinaan dalam rangka mengoptimalkan kegiatan pembelajaran yang berkualitas..

\section{DAFTAR RUJUKAN}

Anita, Lir. 2002. Cooperative Learning. Jakarta: Gramedia Widia Sarana Indonesia. Arikunto, Suharsimi. 1997. Prosedur Penelitian. Jakarta: Rineka Cipta.

Depdikbud. 1998, Pedoman Penyusunan Karya Tulis IImiah di Bidang Pendidikan dan Angka Kredit Perkembangan Profesi Guru. Jakarta: Depdikbud.

Depdiknas. 2004. Kurikulum 2004: Pedoman Pengembangan Silabus Kelas III s.d. VI, Jakarta: Depdiknas.

Ibrahim, R. 1991. Pengembangan Inovasi dan Kurikulum, Jakarta: Universitas Terbuka.

Khafid, MK. 2004. Matematika Untuk Sekolah dasar Kelas IV. Jakarta: Erlangga.

Santoso, Barokah. 1998. Cooperative Learning. Surabaya: Dinas Pendidikan dan Kebudayaan Provinsi Jawa Timur.

Sardiman, AM. 1987. Interaksi dan Motivasi Belajar Mengajar. Jakarta: Rajawali Pers.

Silberman, M.L. 2002. Active Learning. 101 Cara Belajar Siswa Aktif. Bandung, Nuansa dan Nusamedia.

Sutrisno, Hadi. 1986. Metodologi Research. Yogyakarta: Universitas Gajah Mada. 